\title{
THE MUSHARRAF FORMULA (BACKCHANNEL FORMULA) AND THE RESOLUTION OF THE KASHMIR CONFLICT
}

\author{
Dr.Saeed Ahmed Rid \\ Assistant Professor, National Institute of Pakistan Studies, \\ Quaid-i-Azam University, Islamabad \\ Email:saeedrid@gau.edu.pk
}

\begin{abstract}
The Musharraf formula refers to the resolution formula of the Kashmir conflict which was reportedly agreed upon during the one-to-one backchannel dialogue between Mr. Tariq Aziz, the former civil servant and close aide of the then President of Pakistan, General Pervez Musharraf and Mr.Satinder Lambah, a special envoy of the Prime Minister of India. We now know some of the details of this formula from the article of the American journalist, Steve Coll which he had published in New Yorker in March 2009 and the book of Mr.Khursheed Mahmud Kasuri, 'Neither a Hawk nor a Dove' which was published in 2015. Prior to this Mr.Musharraf and Mr.Kasuri had already claimed in their TV interviews and press talks that by March 2007 India and Pakistan were very close to resolving the Kashmir conflict. This paper takes the details of that nonpaper agreement and tries to study what exactly that agreement holds for the future resolution of the Kashmir conflict. The basic understanding is whenever the Pakistani and the Indian governments will take up the negotiations on the Kashmir conflict in future, this agreement is bound to come up in the talks as a starting reference point. Therefore, it is necessary to carefully look at this agreement and discuss what it entails for the resolution of the Kashmir conflict.
\end{abstract}

Keywords: Kashmir conflict, India-Pakistan Relations, Backchannel negotiations, Peace Process

\section{INTRODUCTION}

Whenever things threatened to fall apart during our negotiationsand they did on many occasions- we would stand back and remind ourselves that if negotiations broke down the outcome would be a bloodbath of unimaginable proportions, and that after the bloodbath we would have to sit down again and negotiate with each other. The thought always sobered us up and we persisted, despite many setbacks. You negotiate with your enemies, not your friends (Nelson Mandela, South Africa, 1997). 
In year 2009 several statements were made by the officials involved in backchannel diplomacy between India and Pakistan which claimed that Pakistan and India were near deal over Kashmir by March 2007. The most important and perhaps the most prominent statement in this regard was that of the former Foreign Minister of Pakistan, Mr.Khursheed Mahmud Kasuri who must have had the direct access to all information regarding those backdoor talks. In February 2009, Mr.Kasuri claimed in an interview to the Indian TV channel CNN-IBN that by March 2007 the two sides were close to working out the outline of a solution for the Kashmir conflict. This resolution formula was planned to be announced during the Indian Prime Minister, Manmohan Singh's official trip to Pakistan in July 2007. Moreover, Mr.Kasurihad also confirmed the widely circulated story in the press that this deal could not come through because of the then President Pervez Musharraf's internal problems specially controversy over reference against the then Chief Justice of Pakistan, Iftikhar Mohammad Chaudhari.

It would be interesting to know how the two sides had reached at that stage and whether such a deal could find favour with the people of India, Pakistan and Kashmiris on both sides of the divide. This paper looks at whether such a resolution formula was in the offing considering the negotiations that were taking place between the two countries or this whole story is like a fairy tale which has nothing to do with the situation on ground. If India and Pakistan were closer to resolving the Kashmir conflict in their negotiations, then that would mean the Kashmir dispute is no more an intractable conflict and that resolution is possible.

To achieve this, the resolution formulae being discussed in postcold war era are studied, specially focusing on the ones which received some support from the governments of India and Pakistan. Studying the favoured resolution formulas of India and Pakistan would help to understand the type of solution which the two countries were gradually arriving at in their negotiations. Here we must point out that the purpose of discussing those formulas would be to find out what ground was covered and not to critically analyse which formula could be more suitable per se. If the study confirms the two sides were arriving at the same kind of resolution formula which is told in the story above, then it will prove that the two sides might have reached close to resolving 
the Kashmir imbroglio. But still whether such a resolution formula would have gained the support of all important stake-holders in the conflict must be a million dollars question.

\section{RESEARCH QUESTIONS}

The main research question of this research paper is to study whether backchannel formula represented the collective wisdom that has evolved through the history of the negotiations over Kashmir between India and Pakistan or it goes completely against that collective wisdom? Moreover, whether this resolution formula seriously provides a possible out of the box solution for the Kashmir conflict or it has no standing vis-à-vis resolution of the Kashmir conflict?

\section{AIMS OF THE RESEARCH}

1- To study the resolution formulas discussed so far for the resolution of the Kashmir conflict.

2- To understand the context in which Musharraf Formula (Backchannel Formula) was formulated.

3- To analyse how far the Musharraf Formula provides an out of the box solution and a realistic workable solution of the Kashmir conflict.

4- To understand and highlight the importance of this formula for future negotiations on Kashmir.

\section{SEARCH FOR THE RESOLUTION FORMULA ON KASHMIR}

In the context of Kashmir conflict, former Pakistani President Pervez Musharraf deserves a credit for starting the process of invention by putting several new proposals before the Indian leadership. On the other hand, Indian leadership appeared tight lipped over Kashmir except for the proposals of "open borders" and "selfrule" made by PM Manmohan Singh in response to the Musharraf proposals. Fisher and Ury are absolutely right, "If the first impediment to creative thinking is premature criticism, the second is premature closure. By looking from the outset for the single best answer, you are likely to short-circuit a wiser decision-making process in which you select from a large number of possible answers" (Fisher and Ury 1991: 59). 
The Indian reluctance rather unease on talking Kashmir has been a common feature in the last seventy years' India Pakistan dialogue. When we study different conflict resolution formulas and negotiations on Kashmir, this feeling gets stronger and more pronounced. In fact, during India's first Prime Minister, Jawaharlal Nehru's times Kashmir became so much ingrained in New Delhi's mindset that any possibility of losing Kashmir upsets the whole process of peace building. The London Times wrote on September 06, 1950, "Like most great men, Nehru has his blind spot. In his case it is Kashmir, the land of his forebears which he loves 'like a woman'. Because he is not amenable to reason on this subject, but allows emotion to get the better of common sense, Kashmir remains a stumbling block in the path of Indo-Pakistan friendship" (Korbel 1954:175).

\section{The Old Proposals}

Nonetheless, on Kashmir there has been no dearth of proposals and resolution formulae coming from the Kashmiri leaders, United Nation's representatives, politicians, thinkers, intellectuals, writers and research institutions. In the early phase, United Nations tried its best to resolve this dispute through professional mediators and arbitrators. But the proposals made by the UN representatives, General McNaughton, Sir Owen Dixon and Frank P. Graham failed to satisfy the two contending parties. Those early proposals are discussed in some detail by Korbel (1954), Burke, and Ziring (1990), Amin (1995) and Lamb (1997). Among those early proposals Owen Dixon proposals stand out because one can still hear the echo of Owen Dixon proposals in some of the current proposals under discussion.

The Security Council appointed Sir Owen Dixon, a renowned Judge of the Australian High Court as a UN representative for India and Pakistan to prepare and supervise a programme for the demilitarization of the Kashmir state and prepare ground for a fair and just plebiscite (Tahira 1990:89). Owen Dixon arrived in the subcontinent on May 27, 1950 and stayed until August 23, 1950. He suggested several proposals for demilitarization and establishment of a neutral government for holding a genuine plebiscite in Kashmir, but all his proposals proved fruitless because of the negative response from the Indian side. Finally, he pronounced: In the end, I became

convinced that India's agreement would never be obtained to 
demilitarization in any such form, or to any provisions governing the period of the plebiscite of any such character, as would in my opinion permit the plebiscite being conducted in conditions sufficiently guarding against intimidation, and other forms of influence and abuse by which the freedom and fairness of the plebiscite might be imperilled" (Korbel 1954:172-3).

Therefore, Mr. Dixon then proposed altogether leaving the idea of a 'single plebiscite' conducted in the whole state of Jammu and Kashmir, envisaged in the UN resolutions of August 13, 1948 and January 5, 1949. Rather he proposed a 'limited plebiscite' in Kashmir based on regional divisions, allocating to Pakistan and India the regions according to the result of voting (Tahira 1990:90-91). Owen Dixon further proposed to conduct the plebiscite only in Kashmir valley and allocate all other regions to either Pakistan or India knowing the areas which "unquestionably" would vote for them (Korbel 1954: 173). Famous Indian writer A.G. Noorani reported that almost all important national leaders of the Indian National Congress which included Nehru, Sardar Patel, Rajendra Prasad and Abdul Kalam Azad had agreed with this Owen Dixon proposal at one point but later on Nehru backed out because of the disagreement on conditions under which a plebiscite should be held in the Kashmir valley (The Frontline, October 12-25, 2002). Nehru wanted that plebiscite must be held under Sheikh Abdullah, the then Prime Minister of the Indian held Kashmir, a condition which was considered totally unfair by Sir Owen Dixon and in no way, could have been acceptable to Pakistan.

Later, the search for proposals slowed down considerably as the internal politics in Indian held Kashmir took different turns. Nevertheless, a half-hearted attempt was made by the United States and United Kingdom in 1962-63 to resolve the Kashmir issue so that India can focus on Chinese threat single-handedly. Six rounds of talks were held between the delegations led by Swaran Singh and Zulfiqar Ali Bhutto between December 27, 1962 and May 16, 1963. During these talks India once again offered Pakistan to make the ceasefire line a permanent international boundary with some minor modifications. Earlier back in May 1955, Nehru had offered Pakistan a permanent de jure division of Jammu and Kashmir along the ceasefire line (Bose 2003:72). According to some Indian sources exactly 3,500 square 
kilometres territory along the ceasefire line starting from Zoji La in the north to near Jhangar in the South were offered to Pakistan (Koithara 2004:37). But Pakistan insisted on some form of self-determination for the people of Kashmir. Thus neither Pakistan nor India was ready to give any concessions on their basic position vis-à-vis Kashmir. Dennis Kux rightly points out that 1962-63 talks failed precisely because, "neither India nor Pakistan was willing to make an offer that the other would consider a basis for serious discussion" (Kux 2006:29).

The failure of 1962-63 talks in a way led India and Pakistan to 1965 war and then came 1971 war because of the East Pakistan crisis. After the Simla Agreement in 1972 Kashmir could not feature in India-Pakistan dialogue until Lahore Declaration 1999 because of the Indian insistence on Kashmir being its 'integral part' and their position that no internationalization of the Kashmir conflict would be allowed according to their interpretation of the Simla Agreement. Thus, during this phase almost no progress was made regarding resolution of the Kashmir conflict.

\section{THE NEW PROPOSALS}

After the nuclearization of South Asia in May 1998, a search for the resolution proposals had intensified and several new proposals came on surface. Various formulae and models were discussed in the academic and political circles based on individual and collective research and successful conflict resolution formulae tried in different parts of the world. There is a long list but the prominent among them were, the Andorra model, the Aland Island model, the South Tyrol solution, the Northern Ireland model, the Trieste-like solution, the Chenab formula (put forwarded by Pakistani backchannel diplomat Niaz A. Naik and supported by Sardar Sikandar Hayat Khan, the former Prime Miniter of Azad Kahmir), Maximum Autonomy on Article 370 model (pro-India Kashmiri leaders Omer Abdullah of National Conference and Mehbuba Mufti of PDP support this formula), Sumantra Bose proposals.

Discussing all these proposals is beyond the purview of this paper, here only different variants of Andorra model and the Sumantra Bose model are discussed because these two models are closer to the proposals of former Pakistani President Pervez Musharaf and the Indian Prime Minister Manmohan Singh respectively. The different variants of these two models are discussed in connection with the 
different statements coming from Musharraf and Manmohan Singh to understand the type of resolution scheme the two sides were arriving at.

\section{ANDORRA MODEL}

Among all proposed schemes on Kashmir, Andorra model has so far received the biggest support from different circles in both India and Pakistan and at international level. The crux of the Andorra strategy seems to be, give 'self-rule' with maximum autonomy to Kashmiris and carve out an autonomous entity whose existence is guaranteed jointly by India and Pakistan- a kind of joint management. Like Kashmir Andorra was a princely state divided into two parts under French and Spanish control with very little local say in the administration. From 1278 Andorra was a point of tension between France and Spain until 1993 when the two sides agreed to share responsibility for the defence of Andorra and give it autonomy close to complete independence. Even Andorra became a member state of the United Nations in 1993. Since then Andorra is a co- principality of the Bishop of Urgel (Spain) and the French President. Both the Bishop of Urgel (Spain) and the French President together constitute titular head of the state, but real executive authority belongs to the locally elected Prime Minister in Andorra.

Andorra model received tremendous support from the key officials and academics in India and Pakistan. The famous Indian journalist and a peace activist, Kuldip Nayyar; prominent Indian writer, Khushwant Singh; famous Pakistani peace activist and one of the authors of PPP manifesto, Dr.Mubashir Hassan; all proposed something very close to the Andorra model. Even Musharraf proposals were also very much in line with the Andorra model. Among the Kashmiri leadership, Mirwaiz Omer Farooq the chief of his faction in All Parties Hurriat Conference (APHC) was the first person who forwarded the solution of the Kashmir dispute on Andorra model in a press conference in September 2004 (The Times of India, September 27, 2004).

At international level, a systematic study was done on Andorra model for Kashmir by the US based Kashmir study group (KSG). The KSG website (www.kashmirstudygroup.net) claims that their proposal was "developed in consultation with persons from the Jammu and Kashmir region from both sides of the Line of Control and with 
Indians and Pakistanis". All above mentioned proposals are important but for the purpose of this research we shall focus only on Kashmir study group (KSG) report in comparison with General Musharraf's formulas.

\section{THE KASHMIR STUDY GROUP PROPOSALS}

The Kashmir study group (KSG) which was established in 1996, and headquartered in Larchmont, New York, in collaboration with the Center for Strategic and International Studies (CSIS) in Washington, presented their twice revised and improved proposals based on Andorra model in their report "Kashmir- A way forward 2005" in February 2005. The KSG report claimed that they had tried to come up with a proposal which considered the sensitivities of all of the stakeholders and satisfied the needs of all parties to the dispute.

The Kashmir study group proposed dividing Kashmir into five regions. Out of those five regions, the three entities included Indian administered regions of Jammu, Kashmir and Ladakh, and the other two entities consisted of Northern Areas and Azad Kashmir under Pakistani control. They also proposed constituting an all Kashmir body (joint mechanism) to coordinate areas of broader interest concerning all five regions such as regional trade, tourism, and water resources. This all Kashmir body included the representatives of India and Pakistan along with the representatives from all five regions of Kashmir.

The KSG suggested that the five regions would be selfgoverning entities enjoying free transit of people, goods, and services to one another and with both India and Pakistan. Each of the new entities would have its own democratic constitution, as well as its own citizenship, flag, and legislature which would legislate on all matters other than defence and foreign affairs. India and Pakistan would be responsible for the defence of the entities, and the entities would maintain police forces to maintain internal law and order. The Line of Control (LoC) would remain intact until such time that both India and Pakistan become ready to alter it in their mutual interest. However, in the meanwhile LoC would be a porous border which Kashmiris on both sides can cross freely.

Late Niaz A. Naik, the famous Pakistani diplomat involved in back channel diplomacy with India said these proposals crystallised the two parties' ideas on 'soft border' and helped towards an 
agreement on starting bus service between Srinagar and Muzzaffarabad in 2005 (Khan 2008:8). Moreover, Khursheed Mahmud Kasuri in his book Neither a Hawk, nor a Dove has also specifically mentioned this proposal and expressed this proposal played an instrumental role behind Musharraf's four-point solution formula.

THE MUSHARRAF INITIAL PROPOSITIONS IN 2004

As opposed to the KSG's five entities, in his October 2004 proposal Musharraf suggested the division of Kashmir into seven regions. They are: two regions of Azad Kashmir and Northern areas under Pakistani control and five Indian administered regions, Jammu, Rajouri-Poonch (Muslim dominated part of Jammu), Kashmir Valey, Kargil (Shia and Balti population-a part of Laddakh) and Laddakh (Akhtar 2007-08:11). Elaborating his solution Musharraf said, "Identify the region, demilitarise it and change its status" (Daily Times, October 14, 2008). In his proposal Musharaf also suggested, a region within Kashmir could be identified that could be demilitarized, and converted into a region under UN, a condominium or some similar arrangement. By this he probably wanted to suggest India can retain Hindu majority regions of Jammu and Buddhist dominated Ladakh and Pakistan can keep the Northern areas of Gilgit and Baltistan and Kashmir valley including Azad Kashmir should become an autonomous region, a condominium, or under UN control.

However, Indian scholars blamed Musharraf for dividing Kashmir on communal lines by creating seven regions against KSG's five. They argued that Musharraf was trying to carve out Muslim majority areas Rajauri, Poonch and Doda from Jammu and Kargil from Laddakh regions for Pakistan on communal lines. Reddy (2004) in his article blamed Musharraf for further dividing Jammu and Laddakh on communal lines into Muslim and Non-Muslim regions along the Chenab River, referring to the Chenab formula already rejected by the Indian government. Whereas, Parkash Nanda in Indian Defence Review equated Musharraf plan with both Chenab formula and Owen Dixon's historical plan and termed it the greatest mischief against India (Nanda 2004). Thus, initially Musharraf proposals could not generate a positive response from India. 


\section{SUMANTRA BOSE PROPOSALS}

In 2003, Sumantra Bose wrote a book titled 'Kashmir: Roots of Conflict, Paths to Peace', where he proposed a solution which is favoured by the most of Indian intellectuals and is very close to the Indian official line. Bose argued in this book that any territorial change in the status quo is not possible and territorial sovereignty of both India and Pakistan over their controlled parts should not be altered. Bose said, "Ways exist of transcending the limitations imposed by those frontiers without abolishing them" (2003: 201-265). He suggested India and Pakistan can establish system of self-rule on their side of the line of control by giving maximum autonomy to their part of Kashmir. The governments of Pakistan and India would be responsible for foreign affairs, external defence, currency, and macroeconomic policy for their own side. They would also be required to cooperate for reducing the scale of violence and human rights violations to provide relief to the Kashmiris.

The Line of Control (LoC) would remain in place, but it would transform from an iron curtain of barbed wire to what he called a linen curtain between self-governing Indian and Pakistani regions of Jammu and Kashmir to promote cross-border economic development and political cooperation. To give an institutionalized form to the peace process Sumantra Bose suggested a permanent intergovernmental council between Indian and Pakistani governments. He suggested cross-border institutional links, such as a cross-border Jammu and Kashmir ministerial council should be created. In his opinion that would serve to integrate the people on two sides of LoC.

Later, in 2004 Indian Prime Minister Manmohan Singh came up with his recipe of 'self-rule' and 'open-borders' which is almost identical with the solution suggested by Sumantra Bose in his book. Manmohan Singh in one of his press statement said India would provide autonomy to the Indian held Jammu and Kashmir and Pakistan should provide the same on Pakistani controlled Azad Kashmir. Explaining his idea of 'self-rule' further he said India will hold authority over currency, defence, election process and judicial system and the Kashmir Government will manage the rest (India Daily, November 20,2004). On open borders or soft borders Indian PM called for making LoC a porous border so that there could be 'free flow of ideas and people' between the two parts of Kashmir which will, according to him, one day make 'LoC irrelevant'. 
G.PARTHASARATHY AND RADHA KUMAR'S "FRAMEWORKS FOR A KASHMIR SETTLEMENT"

The former Indian High Commissioner to Pakistan, G. Parthasarathy and Radha Kumar, further elaborated the thinking within India about "making borders Irrelevant" and "Self-Governance" in their small booklet Frameworks for a Kashmir Settlement published by Delhi Policy Group in 2006. In his proposal, Mr. Parthasarathy advocated using the frameworks of student exchanges and educational institutional links; tourism, agriculture and horticulture cooperation; and environmental cooperation etc across the LoC to expedite the process of making borders irrelevant (2006: 07-09). To enforce these mechanisms, he suggested a high-powered Council of Jammu Kashmir, chaired by the heads of India and Pakistan.

Radha Kumar suggested three tier structures of self-governance for the Indian Held Kashmir, Azad Kashmir and Northern Areas on the basis of Delhi Agreement of 1952 which was signed between then government of India and Shaikh Abdullah and article 370 of the Indian constitution for Jammu and Kashmir which allowed the central control over defence, foreign affairs and communication only (2006: 11-12). According to Radha Kumar, the tier one of the Self-governance would comprise the Centre-State relationship on federal lines between the respective central governments in India and Pakistan and their administered parts of Kashmir on the basis of a consensus on Article 370. The tier two would constitute the internal devolution of power among five regions of Kashmir, in fact same five entities suggested in KSG proposal, with same degree of self-governance as it is offered in tier one. Whereas she suggests the tier three should include the devolution of power to district and municipality or at Punchayat level (2006: 21-22). These proposals help us understand what actually means of "making borders irrelevant" and "self-rule" within Indian academic circles. A separate thorough study is required in Pakistan to probe these ideas and give a Pakistani perspective of "making borders irrelevant" and "self-rule".

\section{HOW NEAR WAS THE RESOLUTION OF THE KASHMIR DISPUTE?}

If we compare the two sets of proposals, Andorra model and Sumantra Bose model, having the tacit support of Pakistani and Indian governments respectively, we can see the actual deadlock has revolved around the status of the Line of Control. The Kashmir study group 
proposal tried to avoid addressing this deadlock and left the option of changing geography along the LoC for future. On the other hand, Musharraf asked for changes along LoC and PM Manmohan Singh and Sumantra Bose wanted to make it a 'porous' or 'soft' but permanent international border

When we compare Musharraf's initial proposal of "selfgovernance" and "demilitarization" with Manmohan Singh's "open borders" and "self-rule", we can observe a lot of common ground is there, but subtle differences are also visible. By "self-governance" and "self-rule" probably both leaders meant the same thing--giving greater autonomy to Kashmir on both sides of the LoC. Musharraf called for 'demilitarization' for obvious reasons because Indian withdrawal of army along LoC would have clearly improved Pakistan's defence on Eastern side and then Pakistan could have concentrated more on its troublesome North-Western frontier with Afghanistan. On the other hand, Manmohan Singh emphasised 'soft border' approach because that would lead to normalization of relations with Pakistan without conceding anything to Pakistan on Kashmir.

The Indian government initially gave the cold shoulder to the 2004 "demilitarization" proposals of Musharraf on the grounds that first of all it was a matter of internal security for India to decide whether to reduce or not to reduce the presence of military personnel within Indian held Kashmir. Secondly, the Indian government said, there can be no demilitarization unless the Pakistan government completely dismantled the network of 'terrorism', which in Indian perceptions was the real cause of unrest in Kashmir. Previously, in response to a call from President Musharraf for troops reduction in Srinagar, Baramulla and Sopore to speed up peace talks between the two nations in May 2006, then Indian defence minister Pranab Mukharjee had demanded from Pakistan government, "I request Pakistan to adhere to its commitment that its land will not be used for cross-border terrorism because as per our information 59 training camps are still functioning in Pakistan."(Dawn, May 10, 2006). It appears that the two sides had clear differences on demilitarization but at the same time we can see differences on demilitarization were not insurmountable provided the two sides could remove their "trust deficit" and the issue of terrorism is dealt with mutual cooperation. 
The issue of terrorism had emerged as one of the biggest stumbling blocks in India Pakistan peace process (2003-2008). Using the strategy of terrorism, the terrorists have successfully derailed the peace process between India and Pakistan whenever they appeared to come closer to each other. Like the Mumbai attacks in 2008 successfully derailed the peace process and when Pakistan and India had announced the schedule for resumption of the Comprehensive Bilateral Dialogue in February 2016,the Pathankot incident happened on January 2, 2016 (Gupta and Rid, 2016) which derailed the process before its resumption. Pakistan argues attaching progress along the peace process with terrorism serves no one's' interest. Pakistan wants the Indian government to understand that derailing the peace process after every single terrorist act in India, actually means playing in the hands of the terrorists because this is exactly what terrorists wanted to achieve. Pakistan believes progress along the peace process and the conflict resolution of long-standing Kashmir dispute would itself help controlling terrorism.

\section{THE MUSHARRAF FORMULA (THE BACKCHANNEL FORMULA)}

The four-point solution of the Kashmir dispute for the first time was proposed by Musharraf in his TV interview to famous Indian journalist, Barkha Dutt on the Indian TV channel NDTV, on December 4 2006, just a few months before the back channel breakthrough in March 2007, further clarified the situation that how far the two sides had gone in their negotiations on Kashmir. The four points included 'soft border', 'self-rule', 'staggered demilitarization' and 'joint mechanism'. Musharraf's four points were: i) Kashmir will have the same borders but people will be allowed to move freely back and forth in the region; ii) the region will have self-governance or autonomy, but not independence; iii) troops will be withdrawn from the region in a staggered manner; and iv) a joint supervision mechanism will be set up, with India, Pakistan and Kashmir represented on it. Musharraf had clearly stated in his interview that if India agreed with his four-point solution Pakistan would give up on the UN resolutions and its longstanding demand for a plebiscite.

Analysing these four points in the light of Manmohan Singh proposals we can safely say that Musharraf and Manmohan Singh had complete agreement on 'self-rule' and 'soft border'. On demilitarization we have already observed that it was basically an 
issue of a lack of trust between the two countries. Therefore, among those four points the possible area of conflict could be a "joint mechanism' where the two sides expected to have serious problems to settle between them.

When we compare Musharraf's four-point solution with the "non-paper" of that back-channel breakthrough which is mentioned in the beginning and is reported by Steve Coll in some detail in the weekly New Yorker on March 02, 2009, we can hardly find any differences between the two. Non-paper is defined as "a text without names or signatures which can serve as a deniable but detailed basis for a deal" (2009: 38). The last version of the non-paper contained, firstly Kashmiris would be given special rights to move and trade freely across the LoC. Hence, a soft border along the LOC. Secondly, both Pakistani and Indian controlled parts of Kashmir would receive same degree of Self-governance. The quantum of self-governance was to be decided in one year within the signing of the agreement (Kasuri 2015). Thirdly, each side would gradually withdraw its troops from the region to reduce them to the bare minimum required for maintaining the law and order and fourthly, a "joint mechanism" made up of local Kashmiri leaders, Indians and Pakistanis, to oversee issues that affect people on the both sides of LoC such as water rights (2009: 46-48).

When we look at the evolution of those resolution formulas which were floating in the air with the backing of respective governments in India and Pakistan in the light of the statements coming from different officials including the former Pakistani President, General Pervez Musharraf and the Indian Prime Minister, Manmohan Singh, it was only "joint mechanism" which was a possible problematic area left in the negotiations. Therefore, it is quite understandable that if India had agreed on the "joint mechanism" then in the light of Musharraf's NDTV interview we can say Mushrraf must have no objection left. We can say, gradually the two sides were arriving at the resolution formula which is provided in that backchannel non-paper and that this formula appears to be well grounded. Kasuri (2015) also reports that the two sides had already agreed in principle on joint mechanism just its detailed were to be sorted out which according to him should not have been a problem as they had already covered so much ground in their negotiations. 
After this thorough discussion there is very little doubt left about whether the two governments led by Mr. Manmohan Singh and Mr. Musharraf had arrived near resolving the Kashmir dispute between them. But this does not automatically qualify that Kashmir was ultimately near a resolution. If really, they were near a resolution what actually stopped them from announcing their resolution formula. So far what has come out is this that the announcement was cancelled because of Musharraf's domestic compulsions due to the judicial crisis in Pakistan and in 2007 there were state assembly elections in Uttar Pradesh and some other states in India. What does it tell us? It tells us that both sides were scared of a possible negative fall-out because the people of India, Pakistan and Kashmir were completely out of the loop in this back-channel diplomacy.

\section{THE CONFLICT RESOLUTION DEAL AND THE PEOPLE OF INDIA, PAKISTAN AND KASHMIR}

The problem lies in the very base of this idea that Kashmir is a territorial dispute between the two countries which could be simply resolved on the negotiation table in bi-lateral negotiations. This approach totally ignores the entrenchment of the Kashmir conflict in the two communities which has taken place over the period of last seventy years. It ignores the fact that very structure of the two parties is now embedded in a pattern of conflictual relationships, that without transforming the structure of the two societies and changing their pattern of relationship, conflict resolution would have a little chance of ensuring durable peace between the two countries and Kashmiris.

This entails without involving the people of India, Pakistan and Kashmir in the peace process and without preparing the people for such a deal no deal is possible on Kashmir. No President or Prime Minister, even a military ruler can agree on anything which is against the wishes of the majority of its people. Even if such a deal is successfully accomplished by the governments of India and Pakistan there is very little chance of durable peace if majority feels betrayed. Furthermore, politically an unpopular deal would be infeasible and dangerous even for the future relations of the two countries. Therefore, Mr.Kasuri, the former foreign minister of Pakistan was absolutely right when he argued that they "should not waste" the non-paper by announcing the deal when Musharraf was not in a position to build a national consensus for the same (Coll 2009:40). 


\section{CONCLUSION}

Hence, this study shows the Andorra model, Kashmir Study Group proposals, Musharraf's 2004 propositions, Sumantra Bose plan and Manmohan Singh solutions all played their role in arriving to the non-paper breakthrough in 2007. In this regard Sir Owen Dixon must also be given a due credit for putting the idea of "regional plebiscite" which opened the gates for all out of the box solutions regarding the Kashmir conflict.

From all the discussion above it becomes clear that the nonpaper arrived during the 'backchannel dialogue' was an outcome of the peace process which was once termed 'irreversible' by Musharraf and Manmohan Singh. Inventing the options of mutual gain by India and Pakistan had helped in narrowing down the differences and opening the new opportunities and hopes of peace and conflict resolution between the two arch rivals. In the light of the backchannel dialogue success, the Kashmir dispute which appeared intractable before, its resolution appears possible provided India and Pakistan can handle their trust deficit and show mutual understanding in their conduct.

\section{REFERENCES}

Akhtar, Shaheen, (2007-08). Role of Leadership in India-Pakistan Peace Process. Regional Studies, Vol.XXVI, No.1, Winter.

Amin, Tahir, (1995). Mass Resistance in Kashmir-Origins, Evolution, Options. Islamabad: Institute of Policy Studies.

Bose, Sumantra, (2003). Kashmir: Roots of Conflict, Paths to Peace. Cambridge: Harvard University Press.

Burke, S.M. and Lawrence, Ziring, (1990). Pakistan's Foreign Policy: An Historical Analysis. Karachi: Oxford University Press.

Chopra, Pran, (2003). Scene Changes in Kashmir, India and Pakistan, New Delhi: Gyan Publishing House.

Coll, Steve, (2009). A Reporter at Large: The Back Channel. The New Yorker, March 2, p.38-51

Fisher, Roger and Ury William, (1991). Getting to Yes- Negotiating Agreement Without Giving In. New York: Penguin Books.

Gilani, Iftikhar, (2004). Spring in Kashmir. Hard News, New Delhi, December.

Gupta, Samir and Rid, Saeed Ahmed, (2016). India Pakistan Relations in 2017 and Beyond. [Online] Amanki Asha website page, December 31, https://amankiasha.com/india-pakistan-relations-in-2017-and-beyond/ (Accessed on August 19, 2020).

Jalil, Muzamil, (2002). A guide to Kashmir Peace Plans. Guardian, January 22. 
Kashmir Study Group, 'Kashmir- A way Forward-2005', February 2005, [Online] Larchmout: USA http://www.kashmirstudygroup.net/ [Accessed on 18 August 2012].

Kasuri, Khurshid Mahmud. (2015). Neither a Hawk nor a Dove: An Insider's Account of Pakistan's Foreign Policy. Karachi: Oxford University Press.

Khan, Rashid, Ahmed (2008). Implementing Kashmir Study Group (KSG) Proposal. IPRI Journal, Vol.VIII, No1, winter.

Koithara, Verghese, 2004. Crafting Peace in Kashmir: Through a realist lens. New Delhi: Sage.

Korbel, Joseph. (1954). Danger in Kashmir. New York: Princeton University Press.

Kux, Dennis, (2006). India-Pakistan Negotiations: Is Past Still Prologue?. Karachi: Oxford University Press.

Lamb, Alastair, (1966). 'Crisis in Kashmir 1947-1966', London: Routledge \& Kegan Paul.

Lamb, Alastair, (1997). 'Incomplete partition-The Genesis of the Kashmir Dispute 1947-1948', Hertfordshire: Roxford Books.

Nanda Parkash, (2004). Kashmir Imbroglio: Whose solution?. Indian Defence Review, New Delhi: Lancer Publishers \& Distributors, Vol.19, No.4, OctDec.

Nayar, Kuldip, (2003). Wall at Wagah-India-Pakistan Relation's. New Delhi: Gyan Publishing House.

Parthasarathy, G. and Radha Kumar, (2006). Frameworks for a Kashmir Settlement. New Delhi: Delhi Policy Group.

Reddy, Muralidhar, 2004. The Musharraf formula. Frontline, The Hindu, Volume 21 - Issue 23, Nov. 06 - 19.

Tahira, Sibtain, (1990). Kashmir and the United Nations. Islamabad: National Institute of Pakistan Studies (NIPS), Qauaid-i-Azam University. 